\title{
Numerical simulation of underground coal gasification process in "Barbara" Experimental Mine
}

\begin{abstract}
This article presents the results of a numerical simulation of the possibility of the underground gasification process of a coal seam located in the "Barbara" Experimental Mine. The purpose of the analyses was to predict the process factors that influence the condition for producing gas that is rich in hydrogen. The georeactor geometry, assumptions for the numerical model, and quantitative and qualitative results of the model studies are presented.
\end{abstract}

Key words: numerical model, underground coal gasification, modeling

\section{INTRODUCTION}

The underground coal gasification process (UCG) is a thermochemical process based on the transformation of the coal seam in-situ into the form of a gas with a specific chemical composition and calorific value. The most-commonly practiced method of the UCG process is drilling directional holes, often referred to in the literature as generator holes, through holes, or gasification channels [2]. The gasification channel fulfills two basic functions; namely, to allow the medium (oxygen, air, etc.) to be transported directly into the reaction space (georeactor), and to capture the synthetic gas. The chemical composition of the gas obtained depends on the types of gasification, pressure, and temperatures used [2, 7, 8].

In addition to experimental research, the numerical modeling of the coal gasification process occupies an important place in the design stage of the whole project. Numerical simulations are carried out with the intention of developing mathematical models of particular phenomena taking place during this process in a finite volume of geometry representing the real object of the research. In addition to the cognitive element, it is also important to be able to control the parameters that directly determine the phenomenon, which is the great practical importance $[2,3,6,9]$.

The results of the research of the UCG process on the example of a real coal seam located in EM "Barbara" were shown. The research was supported by the Computational Fluid Dynamics (CFD) method. The program structure is based on the modules available from the Ansys-Workbench dialog. The structure diagram is shown in Figure 1.

The structure of the program is reminiscent of a database system that enables us to create and manage the relational databases starting from the geometry of the analyzed object (Geometry module) by generating a numerical grid (Mesh module), performing numerical calculations (Fluent module), and creating a numerical solution (Results module) [1].

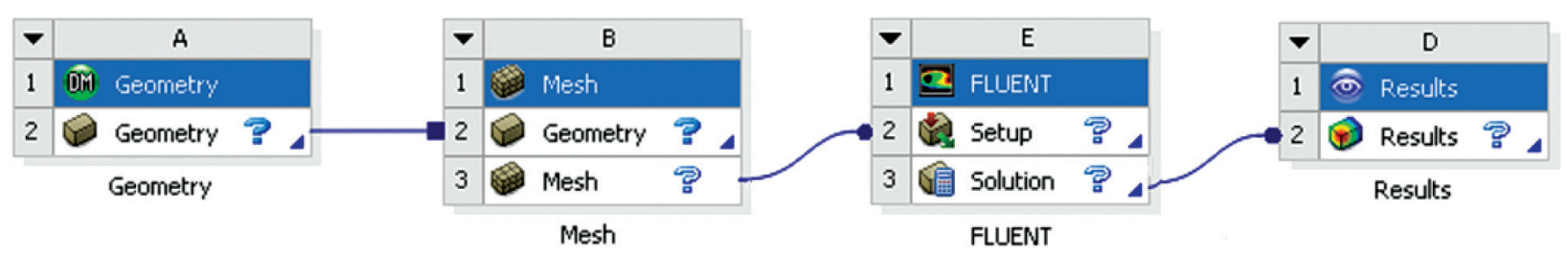

Fig. 1. Data structure in Ansys-Workbench [1] 


\section{NUMERICAL MODEL}

The first stage of modeling is to define the purpose of the modeling, such as the consideration of the physical phenomena, the conditions of the solution of the numerical model, the time needed for the calculation, and the size of the computational model. The second stage is to develop the georeactor geometry that reflects the real object of the research. After creating the geometric model, the next step is to make it discrete so as to define the area of the numerical solution of the analyzed problem. The final step of the modeling process is to properly define the settings for the problem (solver) and perform numerical calculations, focusing on monitoring the convergence of the resulting numerical solution $[6,11]$.

\subsection{Geometry}

The numerical simulation of the UCG process was established within the limits of the coal seam of the EM "Barbara" as shown in Figure 2. The surrounding of the coal seam is a 3-meter-wide and 2.8-meter-high excavation in a steel-concrete casing. The depth of the coal deposit is about $20 \mathrm{~m} \mathrm{[5].}$

The georeactor is a coal seam with an area of $960 \mathrm{~m}^{2}$, thicknesses of 1.5-1.7 m, slope of about $3.5^{\circ}$, and a weight of $2.23 \mathrm{Mg}$. The georeactor's reaction space is a $\mathrm{U}$-shaped cylinder about $0.14 \mathrm{~m}$ in diameter with a total length of $50 \mathrm{~m}$ [5].

\subsection{Numerical grid}

Discretization area of the modeled georeactor system was assembled from the following numerical grids: the geometry mapping the gasification channel and the geometry mapping the coal seam. The numerical grid of the gasification channel (Fig. 3a) was formed from 208,809 straight elements jointed with 49,682 no dal points, while the numerical grid of the coal seam (Fig. 3b) was formed from 1,575,773 straight elements connected by 280,563 nodal points.

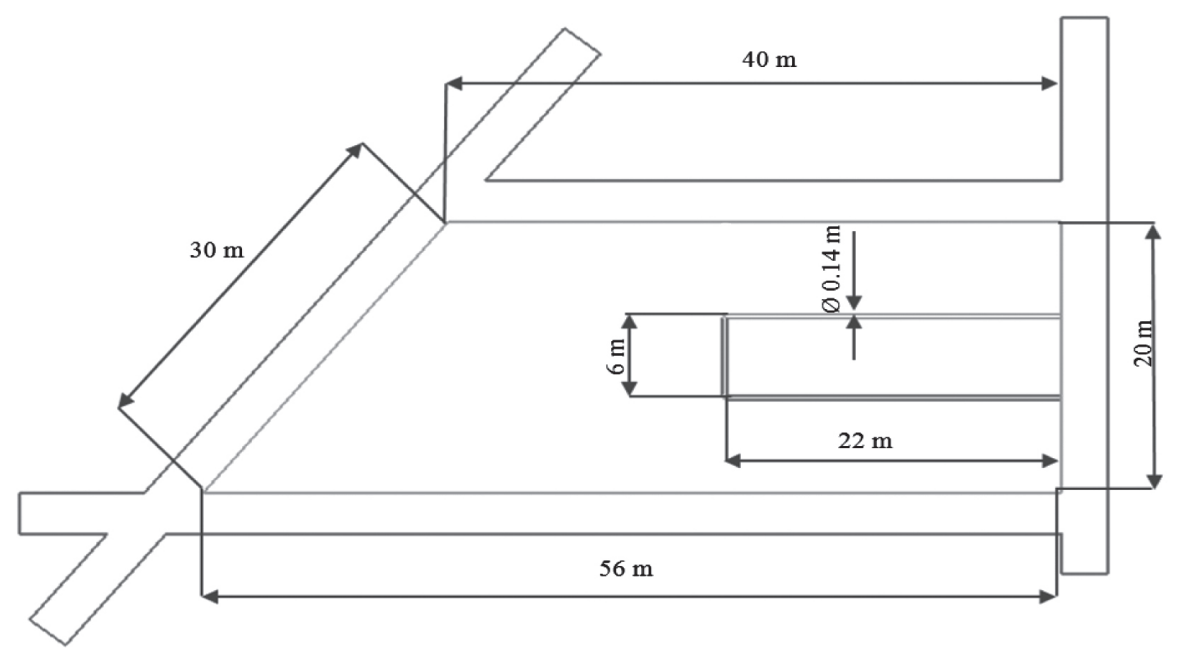

Fig. 2. Horizontal view of basic dimensions of EM "Barbara" coal seam [5]
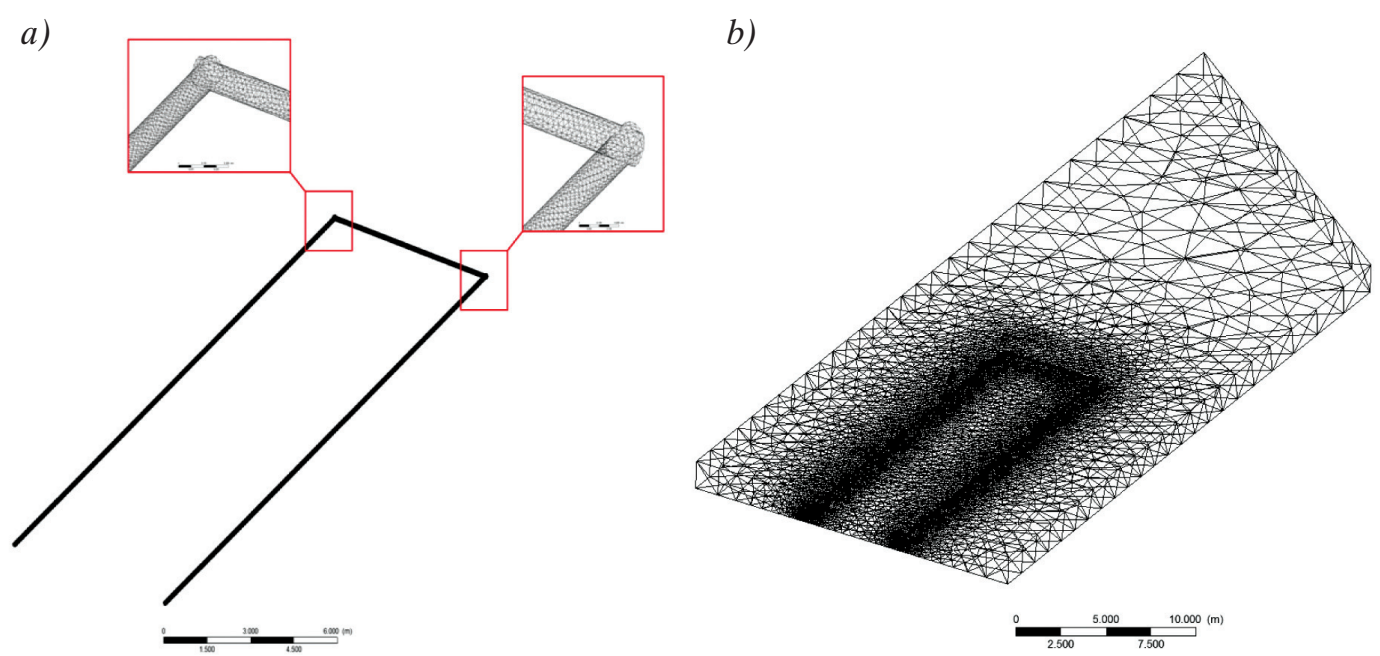

Fig. 3. Numerical grid view of gasification channel (a) and coal seam (b) 
The developed numerical grid was exported to the Ansys-Fluent program in the form of an assembly and treated as a numerical simulation for the accepted conditions of the numerical solution [6].

\subsection{Assumptions}

When analyzing the underground coal gasification process, an important aspect of its effectiveness is the possibility of obtaining information about the quantitative and qualitative distribution of the selected parameters in the reaction space with the given geometry as a function of the time of the phenomenon. The simulation of the fluid flow (aided by the CFD method) is based on solving a set of differential equations that interpret the principle of mass, momentum, and energy conservation with the chemical reactions. Such fundamental equations expressing the fluid flow along the geometry of the gasification channel are the relationships defined in the Ansys-Fluent program as follows:

- mass conservation equation [1]:

$$
\frac{\partial \rho}{\partial t}+\nabla(\rho \vec{v})=S_{m}
$$

- momentum conservation equation [1]:

$$
\frac{\partial}{\partial t}(\rho \vec{v})+\nabla \cdot(\rho \vec{v} \vec{v})=-\nabla p+\nabla \cdot(\tilde{\tau})+p \vec{g}+\vec{F}
$$

- energy conservation equation [1]:

$$
\begin{aligned}
& \frac{\partial}{\partial t}(\rho E)+\nabla(\vec{v}(\rho E+p))= \\
& \quad=\nabla\left(k_{\text {eff }} \nabla T-\sum h_{j} \vec{J}_{j}+\left(\tilde{\tau}_{e f f} \cdot \vec{v}\right)\right)+S_{h}
\end{aligned}
$$

- chemical reaction conservation equation [1]:

$$
\frac{\partial}{\partial t}\left(\rho Y_{i}\right)+\nabla\left(\rho v \vec{Y}_{i}\right)=-\nabla \vec{J}_{j}+S_{i}+R_{i}
$$

where:

$E$ - sum of kinetic energy, potential energy and fluid flow $\left[\mathrm{m}^{2} \cdot \mathrm{s}^{-2}\right]$,

$\vec{F}$ - vector of internal forces acting on the body in cross section $[\mathrm{N}]$

$\vec{g}$ - gravity $\left[\mathrm{m} \cdot \mathrm{s}^{-2}\right]$,

$h$ - enthalpy $\left[\mathrm{J} \cdot \mathrm{kg}^{-1}\right]$,

$\vec{J}_{j}$ - diffusion stream dependent on concentration gradients and fluid temperature $\left[\mathrm{kg} \cdot \mathrm{m}^{-2} \cdot \mathrm{s}^{-1}\right]$,

$k_{\text {eff }}$ - effective conductivity coefficient $\left[\mathrm{W} \cdot \mathrm{m}^{-1} \cdot \mathrm{K}^{-1}\right]$,

$p$ - pressure $[\mathrm{Pa}]$,

$R_{i}$ - chemical reaction rate $\left[\mathrm{kg} \cdot \mathrm{m}^{-3} \cdot \mathrm{s}^{-1}\right]$,

$S_{m}$ - source of mass exchange $\left[\mathrm{kg} \cdot \mathrm{m}^{-3} \cdot \mathrm{s}^{-1}\right]$,

$S_{h}$ - source of the chemical reactions heat $\left[\mathrm{J} \cdot \mathrm{m}^{-3}\right]$,
$S_{i}$ - source associated with the formation of volatile matter $\left[\mathrm{kg} \cdot \mathrm{m}^{-3} \cdot \mathrm{s}^{-1}\right]$,

$t$ - time [s],

$T$ - temperature [K],

$\vec{v}-\operatorname{velocity}\left[\mathrm{m} \cdot \mathrm{s}^{-1}\right]$,

$Y_{i}$ - mass fraction of the fluid component [-],

$\rho$ - density $\left[\mathrm{kg} \cdot \mathrm{m}^{-3}\right]$,

$\mu$ - dynamic viscosity [Pa's],

$\tilde{\tau}$ - stress tensor $\left[\mathrm{kg} \cdot \mathrm{m}^{-3} \cdot \mathrm{s}^{-1}\right]$.

The effect of fluid flow disturbances process was interpreted in the form of a $k-\varepsilon$ turbulence model. The solution of this model based on the solution of the turbidity viscosity values of $\mu_{t}$ using the kinetic energy of vortices $k$ and dissipation rate $\varepsilon$ associated with the energy dissipation due to the internal resistance of the fluid flow along the gasification channel. The fluid flow turbulence $\mu_{t}$ viscosity model is expressed by the equation defined in the Ansys-Fluent as follows [1]:

$$
\mu_{t}=\rho C_{\mu} \frac{k^{2}}{\varepsilon}
$$

The equations of the fluid flow for the kinetic energy of turbulence $k$ and dissipation $\varepsilon$ in Ansys-Fluent are expressed in the following form [1]:

- the energy of kinetic turbulence [1]:

$$
\begin{aligned}
& \frac{\partial}{\partial t}(\rho k)+\frac{\partial}{\partial x_{i}}\left(\rho k v_{i}\right)=\frac{\partial}{\partial x_{j}}\left[\left(\mu+\frac{\mu_{t}}{\sigma_{k}}\right) \frac{\partial k}{\partial x_{j}}\right]+ \\
& +G_{k}+G_{b}-\rho \varepsilon-Y_{M}+S_{k}
\end{aligned}
$$

- the energy dissipation [1]:

$$
\begin{gathered}
\frac{\partial}{\partial t}(\rho \varepsilon)+\frac{\partial}{\partial x_{i}}\left(\rho \varepsilon v_{i}\right)=\frac{\partial}{\partial x_{j}}\left[\left(\mu+\frac{\mu_{t}}{\sigma_{\varepsilon}}\right) \frac{\partial \varepsilon}{\partial x_{j}}\right]+ \\
+C_{1 \varepsilon} \frac{\varepsilon}{k}\left(G k+C_{3 \varepsilon} G_{b}\right)-C_{2 \varepsilon} \rho \frac{\varepsilon^{2}}{k}+S_{\varepsilon}
\end{gathered}
$$

where:

$$
\begin{aligned}
C_{1 \varepsilon} & - \text { empirical constant, } C_{1 \varepsilon}=1.44, \\
C_{2 \varepsilon} & - \text { empirical constant, } C_{2 \varepsilon}=1.92, \\
C_{\mu} & - \text { empirical constant, } C_{\mu}=0.09, \\
k & - \text { fluctuation energy }(\text { turbulence })\left[\mathrm{m}^{2} \cdot \mathrm{s}^{-2}\right], \\
P & - \text { vortex fluctuations, } \\
t & - \text { time }[\mathrm{s}], \\
S_{k} & -\operatorname{source} / \operatorname{sink}\left[\mathrm{kg} \cdot \mathrm{m}^{-3} \cdot \mathrm{s}^{-1}\right], \\
v & -\operatorname{velocity~}\left[\mathrm{m} \cdot \mathrm{s}^{-1}\right] \\
\varepsilon & -\operatorname{dissipation}\left[\mathrm{m}^{2} \cdot \mathrm{s}^{-3}\right], \\
\mu_{t} & - \text { turbulent viscosity }[\mathrm{Pa} \cdot \mathrm{s}], \\
\sigma_{k} & - \text { turbulent Prandtl number, } \sigma_{k}=1.0, \\
\sigma_{\varepsilon} & - \text { turbulent } \operatorname{Prandtl} \text { number, } \sigma_{\varepsilon}=1.3, \\
\rho & - \text { density }\left[\mathrm{kg} \cdot \mathrm{m}^{-3}\right] .
\end{aligned}
$$


The following gasification reaction scheme was adopted for the analyzed issue [1,9]:

$$
\begin{aligned}
& \mathrm{C} \rightarrow \mathrm{C}_{\text {dry }}+\mathrm{H}_{2} \mathrm{O} \\
& \mathrm{C}_{\text {dry }} \rightarrow \mathrm{C}+\mathrm{v} \\
& \mathrm{v}+\mathrm{O}_{2} \rightarrow 1.06 \mathrm{CO}_{2}+0.729 \mathrm{H}_{2} \mathrm{O}+0.012 \mathrm{~N}_{2}
\end{aligned}
$$

where ${ }^{v(} \mathrm{C}_{1.10} \mathrm{H}_{1.45}{ }_{0.93}{ }_{0.0246}{ }^{\mathrm{N}}$ - volatile matter.

Equation (8) interprets the coal-drying process, while Expressions (9) and (10) describe the pyrolysis process.

- surface gasification reactions [9, 11]:

$$
\begin{aligned}
& \mathrm{C}+0.5 \mathrm{O}_{2} \rightarrow \mathrm{CO} \\
& \mathrm{C}+\mathrm{O}_{2} \rightarrow \mathrm{CO}_{2} \\
& \mathrm{C}+\mathrm{H}_{2} \mathrm{O} \rightarrow \mathrm{CO}+\mathrm{H}_{2} \\
& \mathrm{C}+2 \mathrm{H}_{2} \rightarrow \mathrm{CH}_{4}
\end{aligned}
$$

- volumetric gasification reactions $[9,11]$ :

$$
\begin{aligned}
& \mathrm{CH}_{4}+0.5 \mathrm{O}_{2} \rightarrow \mathrm{CO}+2 \mathrm{H}_{2} \\
& \mathrm{CO}+0.5 \mathrm{O}_{2} \rightarrow \mathrm{CO}_{2}
\end{aligned}
$$

The kinetics of the gasification process was defined in the Ansys-Fluent equation as [1]:

$$
k=A T^{\beta} e^{-E / R T}
$$

The parameter values used in the gasification kinetics calculation are listed in Table 1.

\section{Table 1}

Parameters used to calculate chemical reactions of coal gasification process $[1,9,11]$

\begin{tabular}{|c|c|c|c|c|}
\hline \multirow{2}{*}{ No. } & \multirow{2}{*}{ Reaction rate } & \multicolumn{3}{|c|}{ Parameters } \\
\cline { 3 - 4 } & & $\beta$ & $A\left[1 \cdot \mathrm{s}^{-1}\right]$ & $E\left[\mathrm{~J} \cdot \mathrm{mol}^{-1}\right]$ \\
\hline 1. & $R_{8}$ & 0 & $5.1 \cdot 10^{4}$ & $78.24 \cdot 10^{3}$ \\
\hline 2. & $R_{9}$ & 0 & & \\
\hline 3. & $R_{10}=k_{10} \cdot \mathrm{C}_{\mathrm{V}} \cdot \mathrm{C}_{\mathrm{O}_{2}}$ & 0 & $2.12 \cdot 10^{11}$ & $2.03 \cdot 10^{8}$ \\
\hline 4. & $R_{11}=k_{11} \cdot \mathrm{C}_{\mathrm{O}_{2}}$ & 0 & 20.9 & $22.7 \cdot 10^{3}$ \\
\hline 5. & $R_{12}=k_{12} \cdot \mathrm{C}_{\mathrm{O}_{2}}$ & 0 & 5.0 & $13.1 \cdot 10^{3}$ \\
\hline 6. & $R_{13}=k_{13} \cdot \mathrm{C}_{\mathrm{H}_{2} \mathrm{O}}$ & 0 & 12.9 & $36.4 \cdot 10^{3}$ \\
\hline 7. & $R_{14}=k_{14} \cdot \mathrm{C}_{\mathrm{H}_{2}}$ & 0 & 5.0 & $6.1 \cdot 10^{3}$ \\
\hline 8. & $R_{15}=k_{15} \cdot \mathrm{C}_{\mathrm{O}_{2}} \cdot \mathrm{C}_{\mathrm{CH}_{4}}$ & 0 & $4.4 \cdot 10^{11}$ & $1.28 \cdot 10^{8}$ \\
\hline 9. & $R_{16}=k_{16} \cdot \mathrm{C}_{\mathrm{CO}} \cdot \mathrm{C}_{\mathrm{O}_{2}}$ & 0 & $3.16 \cdot 10^{12}$ & $1.67 \cdot 10^{8}$ \\
\hline
\end{tabular}

Coal porosity is a parameter whose value under the conditions of the UCG process changes as a result of the temperature field changes in the volume of coal. Based on work [10] cited by [2] equation defining the value of porosity changes were implemented in Ansys-Fluent as follows:

$$
\varphi=0.2286+0.01041 \cdot T+0.00001786 \cdot T^{2}
$$

where $T$-temperature [K].

The following solution conditions were adopted for each of the numerical grids:

a) for the numerical grid of the gasification channel:

- gasification agent temperature (oxygen, air) $298.15 \mathrm{~K}$,

- volume flow of gas-flying agent (oxygen, air, air with $30 \% \mathrm{O}_{2}$ content, and oxygen mixture) [50\%] - water vapor $(50 \%)-150 \mathrm{Nm}^{3} \cdot \mathrm{h}^{-1}$

b) for the numerical grid of the coal seam:

- density (average value) - $1450 \mathrm{~kg} \cdot \mathrm{m}^{-3}$ [4],

\begin{tabular}{|c|c|}
\hline \multicolumn{2}{|c|}{ Ultimate } \\
\hline Description & {$[\%]$} \\
\hline Moisture & 11.81 \\
\hline Ash & 15.56 \\
\hline Total sulfur & 0.51 \\
\hline Heat of combustion & $21.708\left[\mathrm{~kJ} \cdot \mathrm{kg}^{-1}\right]$ \\
\hline \multicolumn{2}{|c|}{ Proximate } \\
\hline Moisture & 6.39 \\
\hline Ash & 16.52 \\
\hline Volatile mater & 29.84 \\
\hline Heat of combustion & $23.192\left[\mathrm{~kJ} \cdot \mathrm{kg}^{-1}\right]$ \\
\hline Carbon & 57.95 \\
\hline Hydrogen & 3.70 \\
\hline Nitrogen & 0.87 \\
\hline Sulfur & 0.54 \\
\hline Oxygen & 14.03 \\
\hline
\end{tabular}

- porosity (average value) - 5\% [2],

- specific heat $\left(\mathrm{J} \cdot \mathrm{kg}^{-1} \cdot \mathrm{K}^{-1}\right) C_{p_{s}}$ was implemented in Ansys-Fluent [9],

$$
\begin{aligned}
& C_{p_{s}}=\left(0.31+3.38 e^{-4} \cdot(T-546)\right) \cdot 4184 T<598[\mathrm{~K}] \\
& C_{p_{s}}=\left(0.42-1.548 e^{-4} \cdot(T-871)\right) \cdot 4184 T>598[\mathrm{~K}]
\end{aligned}
$$

- initial temperature $T-298.15 \mathrm{~K}$,

- chemical compositions of coal (Tab. 2),

- conduction coefficient (average value) $0.535 \mathrm{Wm}^{-1} \cdot \mathrm{K}^{-1}[4]$.

Table 2

Ultimate-approximate analysis of coal [12] 
Consider the following global (system) settings in Ansys-Fluent:

- pressure: $101.325 \mathrm{~Pa}$,

- convergence of calculations for fluid velocity components, turbulence model parameters, energy equation parameters, continuity parameters: $1 \cdot 10^{-4}$,

- time scale: 100 hours.

\section{RESULTS}

The changes in the characteristics of the chemical composition of the processed gas measured at the georeactor outlet were developed based on the numerical simulation of the analyzed problem depending on the gasification agent used in the calculations within a time interval of 100 hours.

Mass loss rate of coal (parameter mc - Figs. 6, 9, $12,15)$ were estimated based on information about the content of carbon $\mathrm{C}$ measured in the products transported in the processed gas stream at the outlet [8].

In the conditions of the coal gasification process conducted with use of air, the composition of the syngas was predicted to be $68.8 \% \mathrm{~N}_{2}, 7.5 \% \mathrm{H}_{2}, 1.7 \% \mathrm{CH}_{4}$, $8.5 \% \mathrm{CO}_{2}$, and $13.5 \% \mathrm{CO}$ (Fig. 5). The mass loss rate of the coal and cavity growth rate were predicted to be about $0.0183\left[\mathrm{Mg} \cdot \mathrm{h}^{-1}\right]$ and $0.0126\left[\mathrm{~m}^{3} \cdot \mathrm{h}^{-1}\right]$, respectively (Fig. 6). The change of the temperature field was estimated to be between $169.6^{\circ} \mathrm{C}(442.7 \mathrm{~K})$ and $526.4^{\circ} \mathrm{C}$ (799.5 K) (Fig. 7a).

In the case of the coal gasification process realized with the use of air (where the oxygen level is about 30\%), the composition of the syngas was estimated to be $40.9 \% \mathrm{~N}_{2}, 16.3 \% \mathrm{H}_{2}, 3.3 \% \mathrm{CH}_{4}, 12.5 \% \mathrm{CO}_{2}$, and $27 \% \mathrm{CO}$ (Fig. 8). The mass loss rate of the coal and cavity growth rate were predicted to be about $0.0334\left[\mathrm{Mg} \cdot \mathrm{h}^{-1}\right]$ and $0.023\left[\mathrm{~m}^{3} \cdot \mathrm{h}^{-1}\right]$, respectively (Fig. 9). The change of the temperature field was estimated to be between $233.7^{\circ} \mathrm{C}$ (506.85 K) and $750.6^{\circ} \mathrm{C}(1023.75 \mathrm{~K})$ (Fig. 10a).

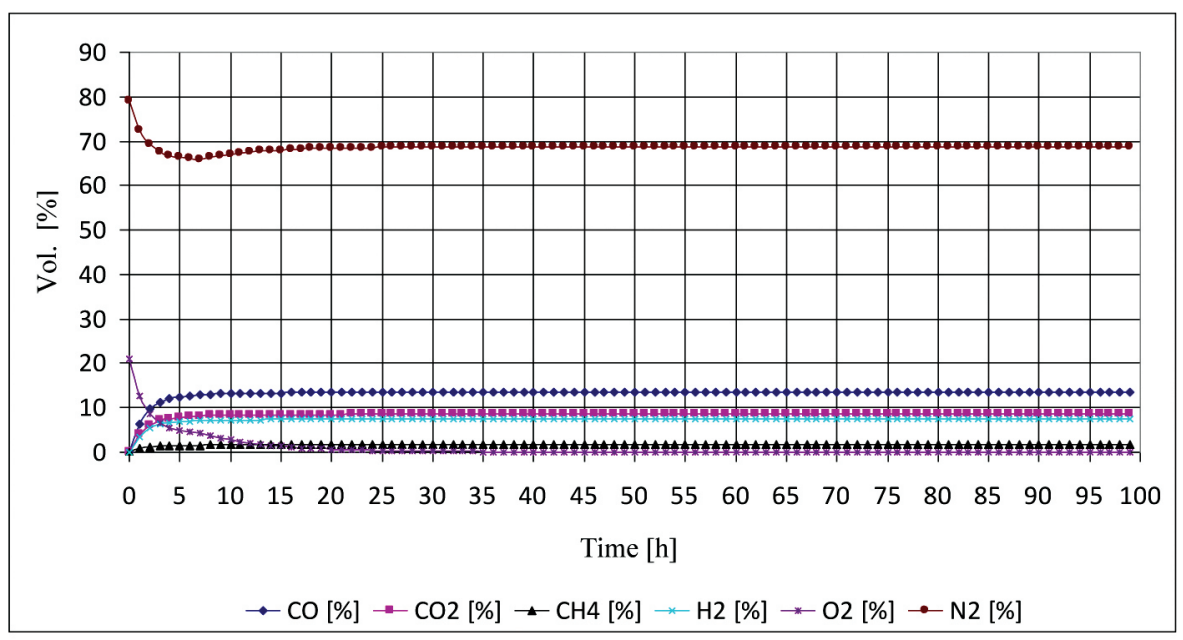

Fig. 5. Changes of processed gas main components under conditions of coal gasification process with use of air

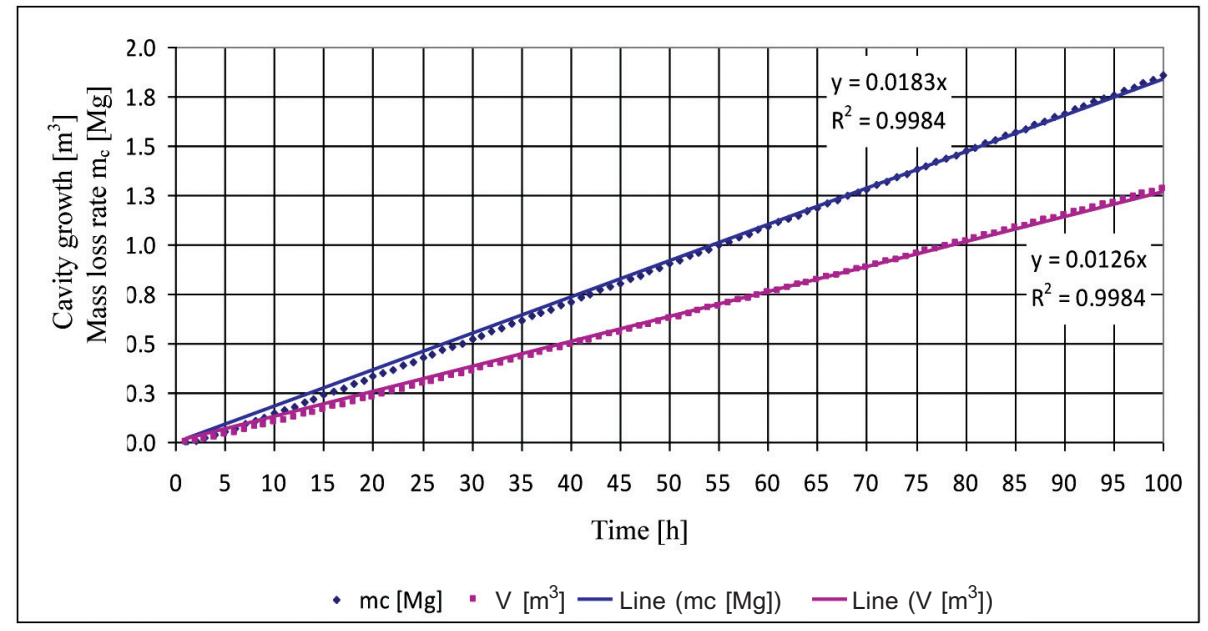

Fig. 6. Changes of cavity growth and coal mass loss rate under conditions of coal gasification process with use of air 
a)

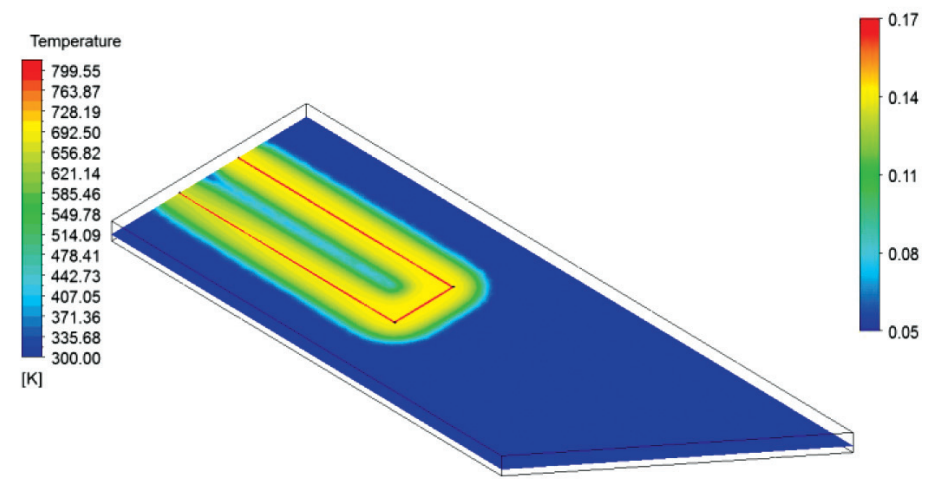

b)

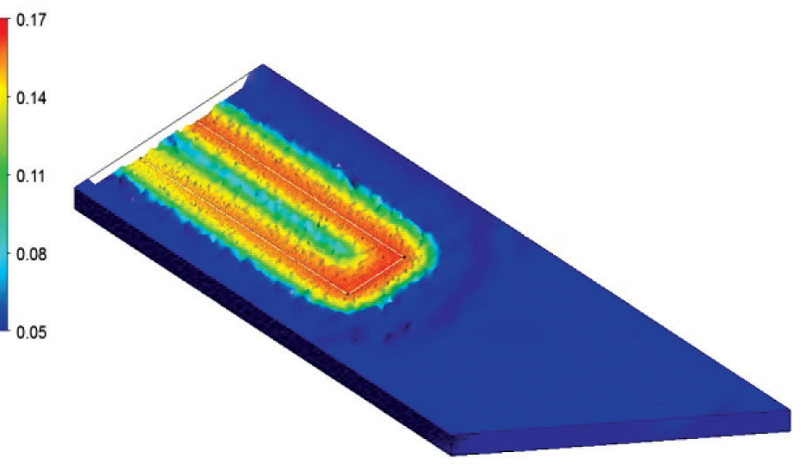

Fig. 7. Change of temperature field (a) and coal seam porosity (b) under conditions of UCG process with use of air

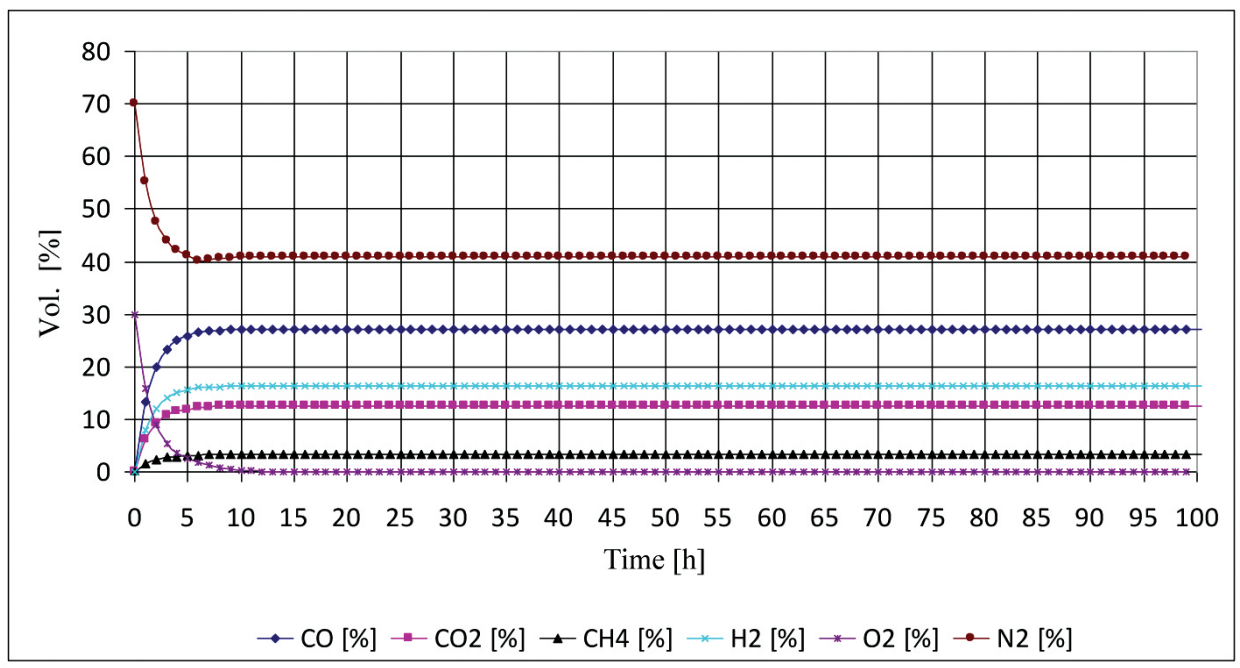

Fig. 8. Changes of processed gas main components under conditions of coal gasification process with use of enriched air

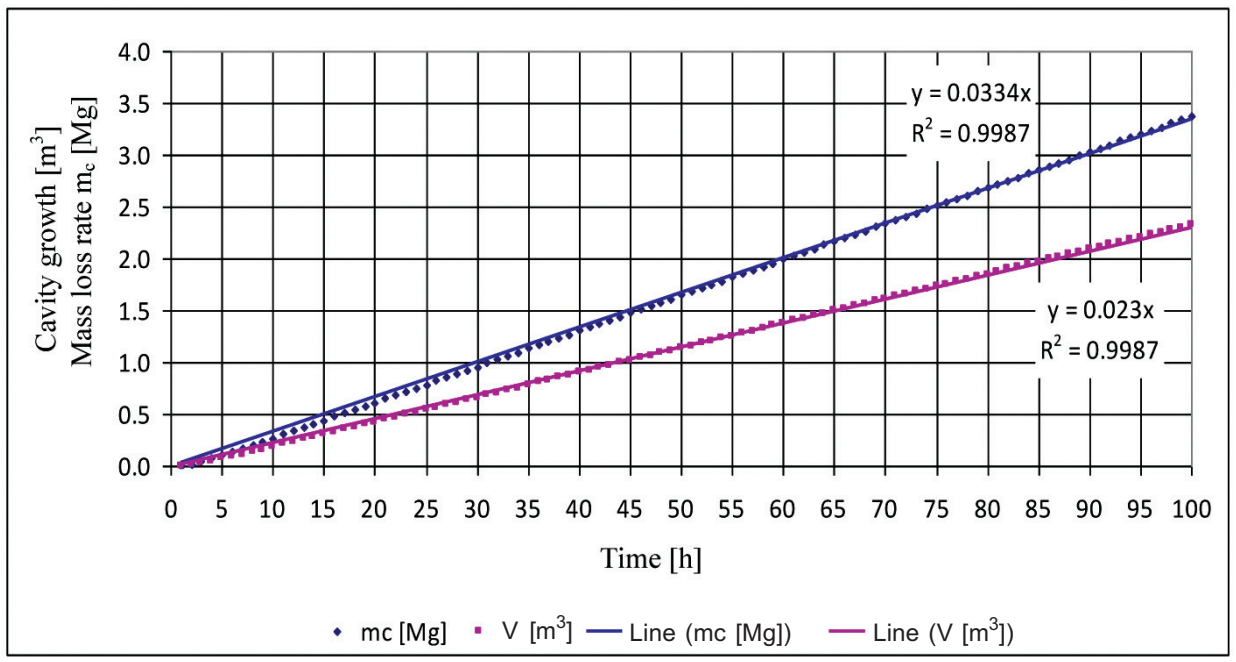

Fig. 9. Changes of cavity growth and coal mass loss rate under conditions of coal gasification process with use of enriched air 
a)

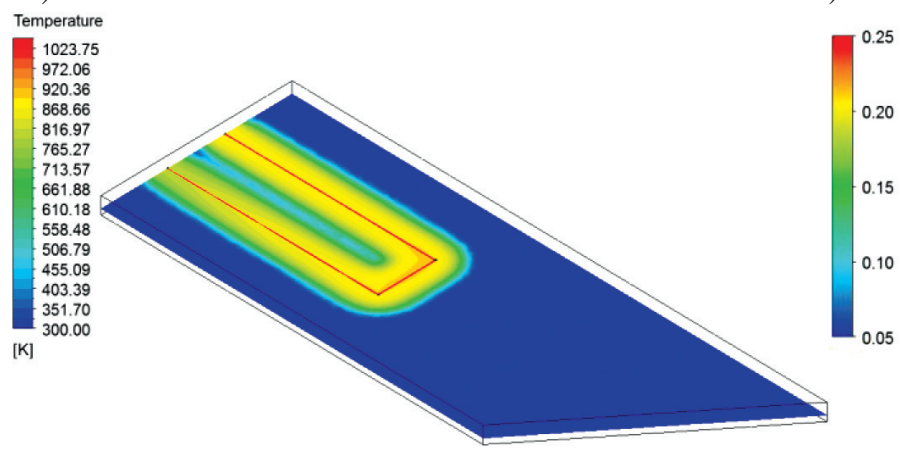

b)

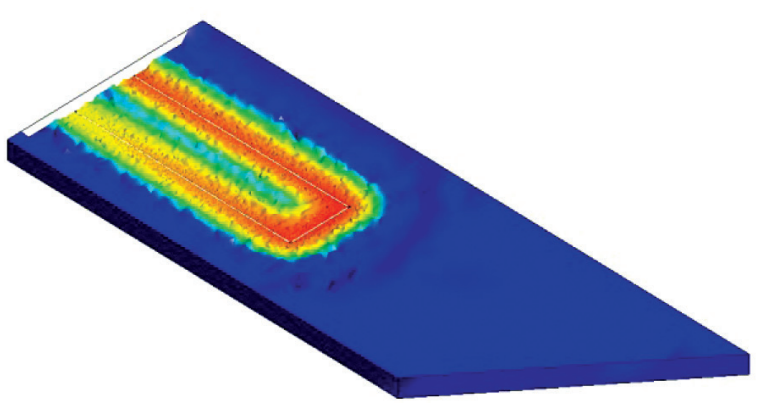

Fig. 10. Change of temperature field (a) and coal seam porosity (b) under conditions of UCG process with use of enriched air

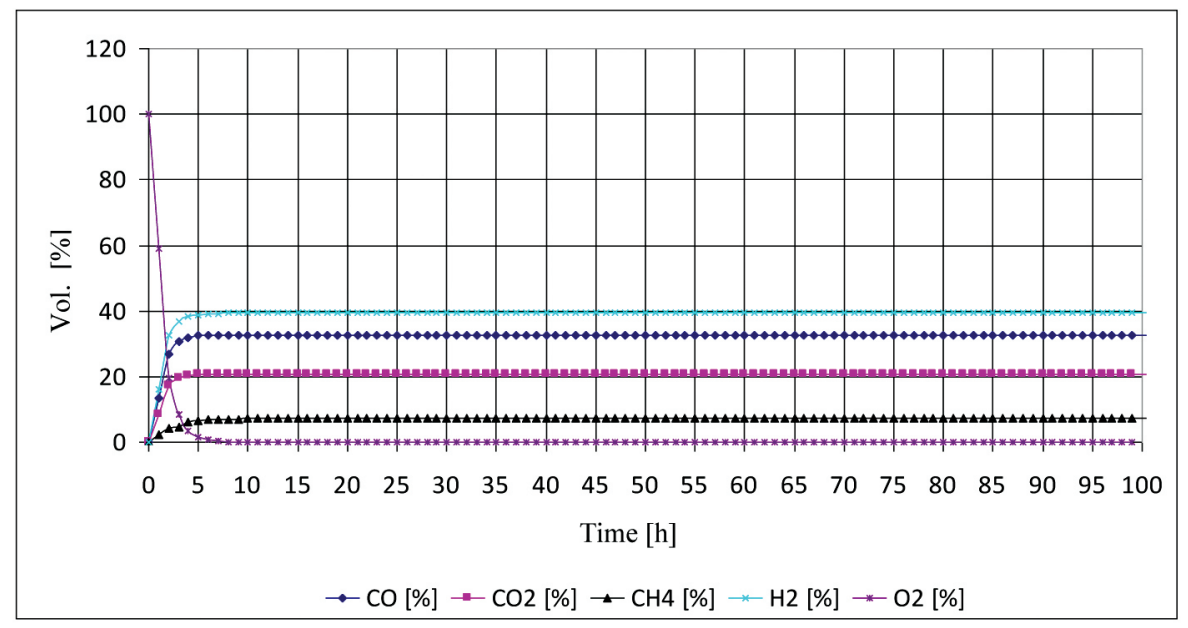

Fig. 11. Changes of processed gas main components under conditions of coal gasification process with use of oxygen

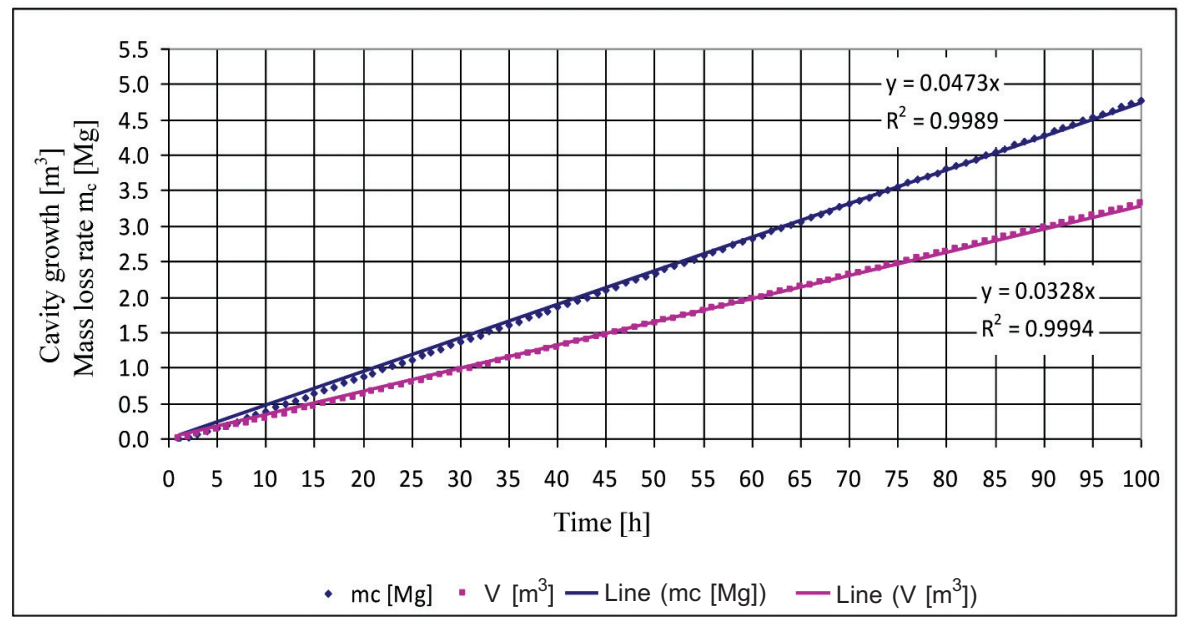

Fig. 12. Changes of cavity growth and coal mass loss rate under conditions of coal gasification process with use of oxygen

In the numerical simulation of the conditions in which the coal gasification process is conducted with the use of oxygen, the composition of the syngas was estimated to be $39.3 \% \mathrm{H}_{2}, 7.1 \% \mathrm{CH}_{4}, 20.8 \% \mathrm{CO}_{2}$, and $32.8 \% \mathrm{CO}$. The mass loss rate of the coal and cavity growth rate were predicted to be about $0.0473\left[\mathrm{Mg} \cdot \mathrm{h}^{-1}\right]$ and $0.0328\left[\mathrm{~m}^{3} \cdot \mathrm{h}^{-1}\right]$, respectively (Fig. 12). The change of the temperature field was estimated to be between $298.8^{\circ} \mathrm{C}(571.95 \mathrm{~K})$ and $1295.9^{\circ} \mathrm{C}(1569.07 \mathrm{~K})$ (Fig. 13a). 
a)

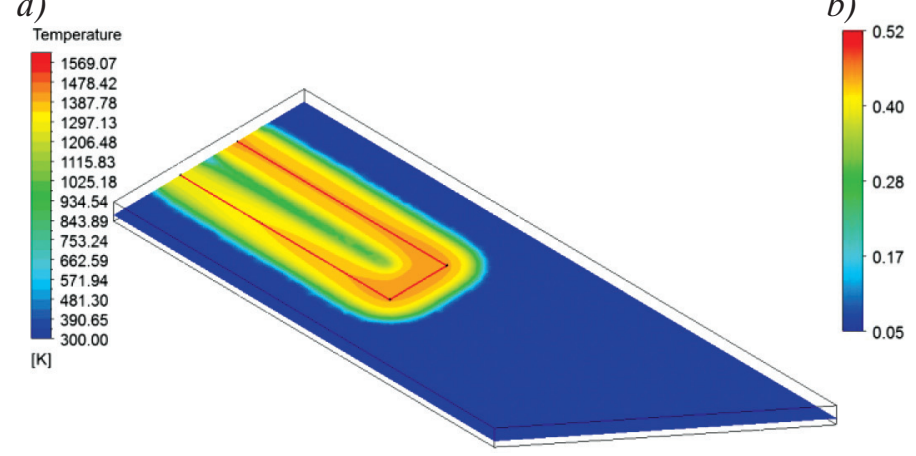

b)

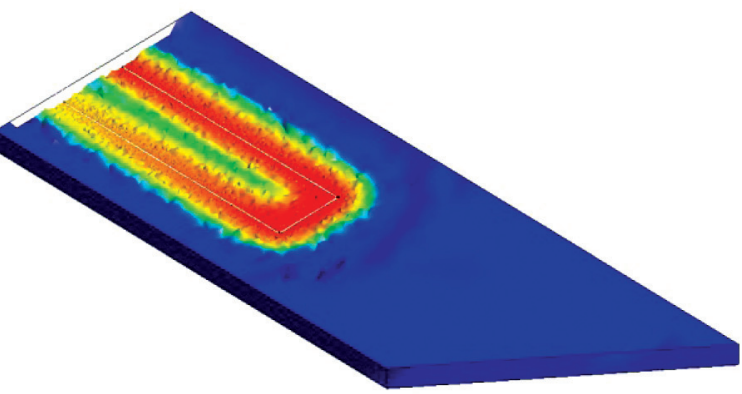

Fig. 13. Change of temperature field (a) and coal seam porosity (b) under conditions of UCG process with use of oxygen

In the numerical simulation of the conditions in which the coal gasification process is conducted with the use of oxygen and water vapor, the composition of the syngas was estimated to be $61.1 \% \mathrm{H}_{2}, 9.6 \% \mathrm{CH}_{4}$, 9.4\% $\mathrm{CO}_{2}$, and $19.9 \% \mathrm{CO}$ (Fig. 14). The mass loss rate of the coal and cavity growth rate were predicted about $0.0307 \mathrm{Mg} \cdot \mathrm{h}^{-1}$ and $0.0214 \mathrm{~m}^{3} \cdot \mathrm{h}^{-1}$, respectively (Fig. 15). The change of the temperature field was estimated to be between $232.4^{\circ} \mathrm{C}(505.55 \mathrm{~K})$ and $986.1^{\circ} \mathrm{C}$ (1259.25 K) (Fig. 16a).

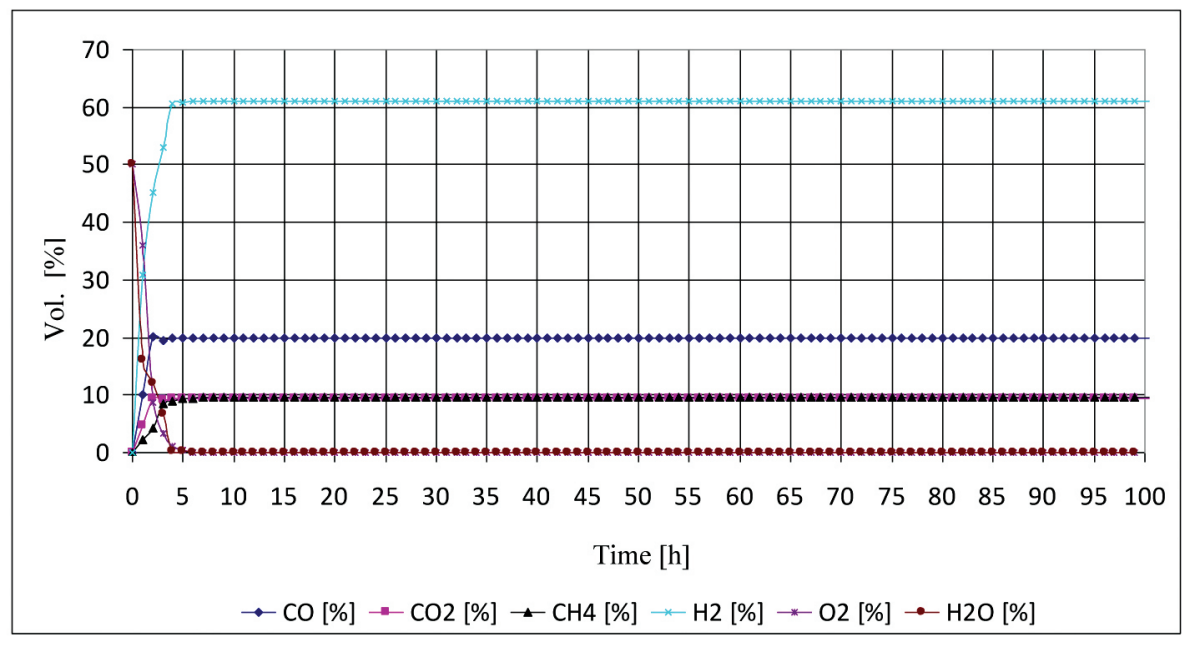

Fig. 14. Changes of processed gas main components under conditions of coal gasification process with use of oxygen and steam mixture

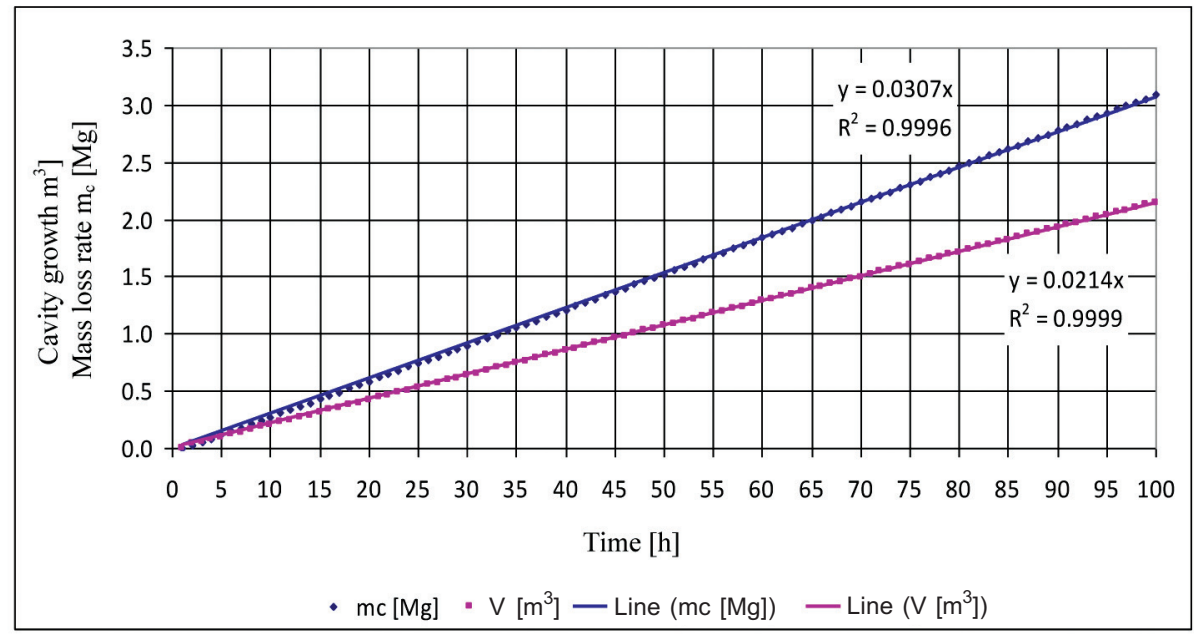

Fig. 15. Changes of cavity growth and coal mass loss rate under conditions of coal gasification process with use of oxygen and steam mixture 
a)

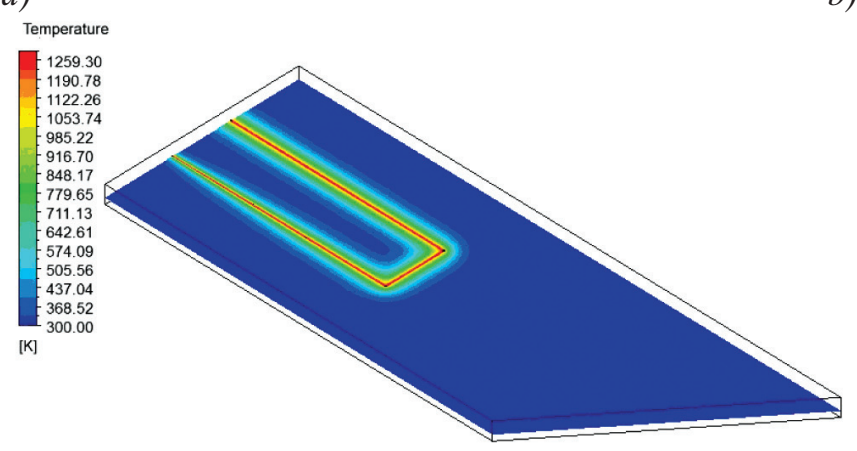

b)

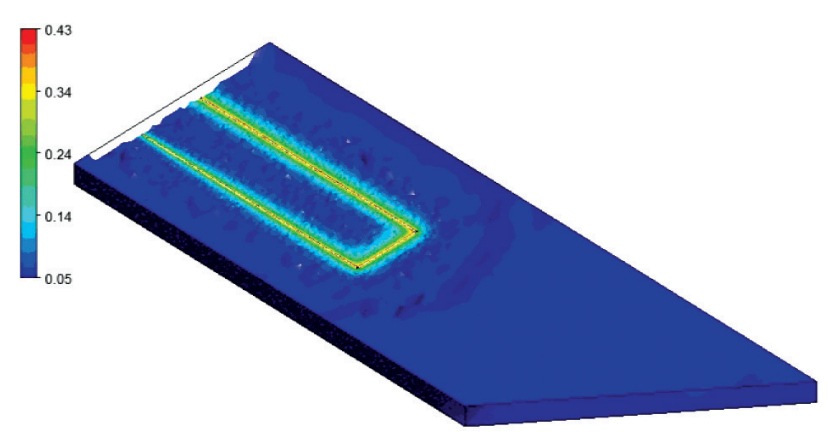

Fig. 16. Change of temperature field (a) and coal seam porosity (b) under conditions of UCG process with use of oxygen and steam mixture

\section{SUMMARY AND CONCLUSIONS}

The numerical model of the underground coal gasification process (UCG) was developed based on the example of a real coal seam in terms of simulating the physicochemical phenomena in the gasification channel and in its surroundings. Tables 3-6 show the predicted average values of the processed gas components that are the results of the numerical simulations of the UCG process.
Based on the numerical simulation, it is possible to obtain processed gas with a content of $\mathrm{H}_{2}$ components within a range of $7.3 \%$ (air) to $59.9 \%$ (mixture of oxygen and steam), $\mathrm{CO}_{2}$ carbon dioxide within a range of $8.3 \%$ (air) to $20.4 \%$ (oxygen), carbon monoxide $\mathrm{CO}$ within a range of $13.2 \%$ (air) to $32.1 \%$ (oxygen), and $\mathrm{CH}_{4}$ methane within a range of $1.6 \%$ (air) to $9.4 \%$ (mixture of oxygen and steam).

On the other hand, the predicted values of the temperature changes in the UCG process along the gasification

Table 3

Average values of processed gas components under conditions of coal gasification process with use of air

\begin{tabular}{|c|c|c|c|c|c|c|c|}
\hline $\mathrm{CO}[\%]$ & $\mathbf{C O}_{2}[\%]$ & $\mathbf{C H}_{4}[\%]$ & $\mathbf{H}_{2}[\%]$ & $\mathbf{O}_{2}[\%]$ & $\mathbf{N}_{2}[\%]$ & $\boldsymbol{m}_{c}[\mathrm{Mg}]$ & $\boldsymbol{V}\left[\mathbf{m}^{3}\right]$ \\
\hline 13.2 & 8.3 & 1.6 & 7.3 & 1.0 & 68.7 & 0.91 & 0.63 \\
\hline
\end{tabular}

Table 4

Average values of processed gas components under conditions of coal gasification process with use of enriched air

\begin{tabular}{|c|c|c|c|c|c|c|c|}
\hline $\mathbf{C O}[\%]$ & $\mathbf{C O}_{2}[\%]$ & $\mathbf{C H}_{4}[\mathbf{\%}]$ & $\mathbf{H}_{\mathbf{2}}[\mathbf{\%}]$ & $\mathbf{O}_{2}[\%]$ & $\mathbf{N}_{\mathbf{2}}[\%]$ & $\boldsymbol{m}_{c}[\mathbf{M g}]$ & $\boldsymbol{V}\left[\mathbf{m}^{\mathbf{3}}\right]$ \\
\hline 20.9 & 9.6 & 4.2 & 18.0 & 0.8 & 46.5 & 1.67 & 1.15 \\
\hline
\end{tabular}

Table 5

Average values of processed gas components under conditions of coal gasification process with use of oxygen

\begin{tabular}{|c|c|c|c|c|c|c|c|}
\hline $\mathbf{C O}[\%]$ & $\mathbf{C O}_{2}[\%]$ & $\mathbf{C H}_{\mathbf{4}}[\mathbf{\%}]$ & $\mathbf{H}_{\mathbf{2}}[\mathbf{\%}]$ & $\mathbf{O}_{2}[\%]$ & $\mathbf{N}_{\mathbf{2}}[\mathbf{\%}]$ & $\boldsymbol{m}_{c}[\mathbf{M g}]$ & $\boldsymbol{V}\left[\mathbf{m}^{3}\right]$ \\
\hline 32.1 & 20.4 & 6.9 & 38.6 & 1.9 & 0.0 & 2.37 & 1.65 \\
\hline
\end{tabular}

Table 6

Average values of processed gas components under conditions of coal gasification process with use of oxygen-steam mixture

\begin{tabular}{|c|c|c|c|c|c|c|c|}
\hline $\mathbf{C O}[\%]$ & $\mathbf{C O}_{2}[\%]$ & $\mathbf{C H}_{\mathbf{4}}[\mathbf{\%}]$ & $\mathbf{H}_{\mathbf{2}}[\mathbf{\%}]$ & $\mathbf{O}_{\mathbf{2}}[\mathbf{\%}]$ & $\mathbf{H}_{\mathbf{2}} \mathbf{O}[\mathbf{\%}]$ & $\boldsymbol{m}_{c}[\mathbf{M g}]$ & $\boldsymbol{V}\left[\mathbf{m}^{\mathbf{3}}\right]$ \\
\hline 19.6 & 9.3 & 9.4 & 59.9 & 1.0 & 0.9 & 1.56 & 1.09 \\
\hline
\end{tabular}


channel are as follows (respectively): for air - 799.5 K $\left(526.4^{\circ} \mathrm{C}\right)$; for enriched air $-1023.75 \mathrm{~K}\left(750.6^{\circ} \mathrm{C}\right)$; for oxygen $-1569.07 \mathrm{~K}\left(1295.92^{\circ} \mathrm{C}\right)$; and for a mixture of oxygen and steam $-1259.30 \mathrm{~K}\left(986.15^{\circ} \mathrm{C}\right)$.

Based on the rate of carbon mass loss within the time interval of 100 hours (depending on the used gasification agent), the mass loss rate was estimated to be as follows:

- for air - loss of $41.4 \%$,

- for oxygen - water vapor mixture - loss of $70.9 \%$,

- for enriched air - loss of $75.9 \%$.

In the case of conducting the UCG process with the use of oxygen, the total available mass was finished after 93 hours.

The results of the numerical simulations allow us to formulate the following conclusions:

- the numerical CFD method used to identify the process factors, process temperature, cavity growth rate, cavity volume, synthesis gas chemical composition, and process time that determined the correctness of the underground gasification process for the given coal seam geometry;

- the most-calorific synthetic gas was predicted for the conditions where a mixture of oxygen and steam was fed to the georeactor's reaction space, while the lowest calorie value was estimated for air.

\section{Acknowledgement}

The work was carried out based on research realized at the Central Mining Institute in Katowice No. 11102026-144 financed by the Ministry of Science and Higher Education.

\section{References}

[1] ANSYS FLUENT 12.0: Theory Guide. ANSYS, Inc. 2009.

[2] Białecka B.: Podziemne zgazowanie wegla. Podstawy procesu decyzyjnego, Wydawnictwo GIG, Katowice 2008.
[3] Bockelie Michael J., Denison Martin K., Chen Zumao, Senior Constance L., Sarofim Adel F.: Using Models to Select Operating Conditions for Gasifiers, Pittsburgh Coal Conference, September 15-19, 2003.

[4] Chmura K.: Przewodność cieplna skat $i$ weggli górnoślaskiego karbonu, Politechnika Śląska, Zeszyty Naukowe nr 190, Gliwice 1968 .

[5] Hildebrandt R.: Opracowanie dokumentacji techniczno-ruchowej procesu PZW, parcela $n r$ 3, KD Barbara, Praca GIG nr 11103096, Główny Instytut Górnictwa, Katowice 2016 [niepublikowana].

[6] Jaworski Z.: Numeryczna mechanika płynów w inżynierii chemicznej $i$ procesowej, EXIT, Warszawa 2005.

[7] Rauk J.: Kształtowanie się kanału ogniowego w podziemnym zgazowaniu wegla kamiennego, "Prace Głównego Instytutu Górnictwa, Seria A, Komunikat nr 241”, Wydawnictwo Górniczo-Hutnicze, Katowice 1959.

[8] Rauk J.: Podstawy interpretacji procesów fizykochemicznych $w$ podziemnym zgazowaniu wegla powietrzem $i$ ich obraz w przeprowadzonych doświadczeniach, "Prace Głównego Instytutu Górnictwa, Seria A, Komunikat nr 246", Wydawnictwo Górniczo-Hutnicze, Katowice 1960.

[9] Shirazi A.S.: CFD simulation of Underground Coal Gasification, University of Alberta 2012.

[10] Seewald H., Klein J., Jungten H.: Pore structure of coal derived from permeation and sorption measurements, Proc. Int. Conf. on Coal Sci., Pergamon Press, Sydney 1985: 861.

[11] Wachowicz J., Łączny J., Iwaszenko S., Janoszek T.: Modelling of Underground Coal Gasification Process Using CFD Methods, "Archives of Mining Sciences" 2015, 60, 3: 663-676.

[12] Wiatowski M., Stańczyk K., Świądrowski J., Kapusta K., Cybulski K., Krause E., Grabowski J., Rogut J., Howaniec N., Smoliński A.: Semi-technical underground coal gasification (UCG) using the shaft method in Experimental Mine "Barbara", "Fuel" 2012, 99: 170-179.

TOMASZ JANOSZEK, Ph.D., Eng. Department of Extraction Technologies and Mining Support Central Mining Institute pl. Gwarków 1, 40-166 Katowice, Poland tjanoszek@gig.eu 